studied. Findings in the patients with Buerger's disease and in the control groups were compared with Fisher's exact test, correcting the level of significance for the total number of antigens considered.

\section{Results}

Ten of the 28 patients referred with presumed Buerger's disease were excluded because they did not fulfill the necessary diagnostic criteria. Of the remaining 18 patients 14 had confirmatory findings on arteriography. All were Caucasian unrelated men, and the mean age of onset of the disease was $33.2 \pm 10.8$ years. All were cigarette smokers, smoking on average $36 \pm 10$ cigarettes a day. The distribution of histocompatibility antigens in this group and in the two control groups is shown in the table. The incidence of HLA-A9 and HLA-B5 was much greater among those with Buerger's disease than in the controls $(P<0.001)$. HLA-A9 and HLA-B5 occurred together in seven $(39 \%)$ of the 18 patients with Buerger's disease but in only nine $(1.5 \%)$ of the 616 healthy controls.

\section{Discussion}

Several diseases have now been reported to show HLA associations. ${ }^{16}$ Ohtawa et $a l^{17}$ first noted an increase in the incidence of HLA-A9, BW10, and a Japanese specific antigen (J-1-1) together with an absence of HLA-B12 in Japanese patients thought to be suffering from Buerger's disease. HLA-B5 was found in $43 \%$ of their patients with the disease, but the difference between this and the $30 \%$ incidence found in their relatively small control group was not significant. In contrast, HLA-B5 in the Merseyside control population was rare $(6 \%)$. We also found that HLA-B12 was absent from our patients compared with a $30 \%$ incidence among controls.

We have shown a significantly increased incidence of HLA-A9 and HLA-B5 antigens in patients who fulfilled strict clinical and arteriographic criteria for the diagnosis of Buerger's disease.
This finding supports the concept that Buerger's disease is a distinct clinicopathological condition separate from early-onset atherosclerosis. While the aetiology of Buerger's disease remains obscure, the published reports indicate that patients are inveterate cigarette smokers. ${ }^{18}$ As the relative risk of patients with HLA-B5 antigen developing the disease is 78.2 , one might speculate the exposure of this phenotype to tobacco is the precipitating factor in the pathogenesis of this disorder.

We thank the surgeons and physicians of the Merseyside region who referred their patients to be studied, Professor $\mathrm{R}$ Shields for his advice and constructive criticism, and the National Tissue Typing Reference Laboratory, Bristol, for supplying the antisera.

\section{References}

${ }^{1}$ Buerger, L, American fournal of Medical Science, 1908, 136, 567.

2 Wessler, S, et al, New England fournal of Medicine, 1960, 262, 1149.

${ }^{3}$ Fisher, C V, Medicine, 1957, 36, 196.

${ }^{4}$ McKusick, V A, et al, Bulletin of the fohns Hopkins Hospital, 1961, 109, 241 .

5 Ishikawa, K, et al, Angiology, 1962, 13, 398.

${ }^{6}$ Szilagyi, D C, et al, Archives of Surgery, 1964, 88, 824.

${ }^{7}$ Inada, K, et al, Archives of Surgery, 1964, 88, 454.

${ }^{8}$ Mozes, M, et al, fournal of Cardiovascular Surgery, 1970, 11, 52.

9 Goodman, R M, et al, American fournal of Medicine, 1965, 39, 601.

${ }_{10}$ Kjeldsen, K, and Mozes, M, Acta Chirurgica Scandinavica, 1969, 135, 495.

11 Samuels, S S, American fournal of Medical Science, 1932, 183, 465.

12 Martorell, F, Angiology, 1952, 3, 271.

13 Weber, F P, Lancet, 1937, 2, 72 .

14 Biddlestone, W R, and Lefevre, F A, Cleveland Clinic Quarterly fournal, $1954,21,226$

15 Dausset, J, in Manual of Tissue Typing Techniques, ed J G Ray, D B Hare, and D C Kayhoe, p 28. Bethseda, Maryland, Department of Health, Education and Welfare, 1973.

${ }^{16}$ Dausset, J, et al, Clinical Immunology and Immunopathology, 1974, 3, 127.

17 Ohtawa, T, et al, fournal of the American Medical Association, 1974, 230, 1128

18 Larson, P S, et al, Tobacco. Experimental and Clinical Studies. Baltimore, Williams and Wilkins, 1961

\title{
Preoperative skin preparation: clinical evaluation of depilatory cream
}

\author{
S J A POWIS, T A WATERWORTH, D G ARKELL
}

British Medical fournal, 1976, 2, 1166-1168

\section{Summary}

Preoperative hair removal by a depilatory cream was compared with routine shaving. Although the incidence of wound infection was similar in both groups, cream depilation was found to be better. It was effective, atraumatic, non-toxic, and could be self-administered. Furthermore, it could be used safely on granulating

\section{General Hospital, Birmingham}

S J A POWIS, CHM, FRCs, lecturer in surgery (now consultant surgeon, General Hospital, Northampton)

T A WATERWORTH, FRCS, senior surgical registrar (now consultant surgeon, Hospital of St Cross, Rugby)

North Staffordshire Royal Infirmary, Stoke-on-Trent

D G ARKELL, MSC, FRCS, senior surgical registrar wounds and did not support bacterial growth. Depilation was associated with a significant reduction in skin surface bacteria and proved to be cheaper than shaving.

\section{Introduction}

Removing hair from the operative site is a time-honoured preoperative exercise. But if shaving is performed more than a few hours before operation the minor abrasions produced provide a good culture medium, with the subsequent risk of wound infection. ${ }^{1-3}$ It has therefore been suggested that immediate preoperative shaving-that is, after anaesthesia has been induced-should be performed. Although this may be surgically desirable it is obviously not possible in busy surgical units. An alternative to shaving is the use of a depilatory agent. Such substances are widely available for cosmetic use but are not commonly used in surgical practice.

We evaluated one preparation (Ipso) and compared it with conventional shaving. After establishing that the depilatory cream was non-irritant and did not support bacterial growth, 
the wound infection rates were compared in two groups of surgical patients.

\section{Patients and methods}

A prospective randomised survey was performed in 92 patients in two hospitals who were undergoing surgery that required removal of hair from the operative site. At the time of admission for surgery consecutive patients who required preoperative hair removal were allocated randomly depending on the last digit of their hospital registration number into a shaving or depilatory cream group (groups 1 and 2 respectively). Skin preparation was performed either one day before surgery or on the day of operation, depending on the preference of the surgeon and the usual practice of the ward. Patients allocated to group 1 had a non-medicated soap applied with water and were then shaved with either a disposable razor or a safety razor with disposable blades. The time taken for this preparation varied considerably, depending on the skill of the shaver, the area to be prepared, the co-operation of the patient, and the density of hair. In view of these variables the time was not measured.

Patients allocated to group 2 received an application of Ipso (5\% calcium thioglycollate trihydrate, calcium hydroxide, and strontium hydroxide in a special emollient base) in accordance with the manufacturer's instructions. A layer of about $2 \mathrm{~mm}$ was applied to the area to be depilated, left for 10 minutes, and then wiped away with a spatula. The area was then washed to remove traces of the cream.

After positioning the anaesthetised patient, the bacterial flora of the skin at the site of the intended incision was sampled by means of a pair of contact plates (Sterilin Ltd, Richmond, Surrey), one containing blood agar and the other MacConkey agar. These were applied immediately before surgical preparation of the skin and were then incubated aerobically at $37^{\circ} \mathrm{C}$ for $18-24$ hours. Total colony counts were recorded, and colonies with the appearance of potential pathogens-that is, Staphylococcus aureus, Escherichia coli, other enterobacteria, and Pseudomonas aeruginosa-were counted separately and subcultured for full identification. In the case of staphylococci, five representative colonies were examined for coagulase and DNase production, and, when positive, morphologically similar colonies were counted as Staph aureus.

The skin round the operative site was then prepared by two applications of $0.5 \%$ chlorhexidine in $70 \%$ spirit. At the end of the operation a deep wound swab was taken and immediately cultured by routine methods including anaerobic culture.

Wounds were examined on the second and fifth days after operation by an independent observer who was unaware of the method of preparation. The wounds were classified as follows: grade $O$, no reaction; grade 1, red around suture line or sutures; grade 2 , red oedematous wound with serous ooze; grade 3 , purulent discharge from wound or sutures, or both; grade 4, dehiscence of part of wound; grade 5, dehiscence of whole of wound. At the same time the surrounding skin was inspected for deleterious effects of the skin preparation, and spontaneous observations by the patients concerning the preparation were encouraged.

The antibacterial properties of Ipso were investigated by mixing it with heavy suspensions of bacteria in saline, from which samples were withdrawn at intervals, and the number of surviving bacteria counted by the method of Miles and Misra. ${ }^{4}$ A $2-\mathrm{ml}$ sample of cream was mixed with $4 \mathrm{ml}$ of saline suspension of the bacteria being tested, while control tubes contained bacteria in saline only. At the end of the experiment $20 \mathrm{ml}$ of nutrient broth was added to each tube and incubated overnight to detect the presence of surviving bacteria.

\section{Results}

Ninety-two patients were studied prospectively, 45 at North Staffordshire Royal Infirmary and 47 at the General Hospital, Birmingham. The operations are shown in table I. While the numbers in each group were small, they were comparable and the anatomical sites were varied, with both major and minor procedures included. The two groups consisted of equal numbers of patients evenly matched for age and sex. Of the 46 patients in group 1,20 were shaved the day before surgery (range 18-24 hours; mean 20.4 hours) and 26 were shaved on the day of operation (range $0 \cdot 5-12$ hours; mean 3.3 hours). Twenty-six of the patients in group 2 were prepared the day before surgery (range 18-24 hours; mean 20.4 hours), and 20 were prepared on the day of operation (range 1-12 hours; mean 4.1 hours).
TABLE I-Operations performed in 92 patients who had hair removed by shaving (group 1) or depilatory cream (group 2)

\begin{tabular}{|c|c|c|c|c|c|}
\hline & $\underset{1}{\text { Group }}$ & $\underset{2}{\text { Group }}$ & & $\underset{1}{\text { Group }}$ & $\underset{2}{\text { Group }}$ \\
\hline $\begin{array}{l}\text { Herniorrhaphy } \\
\text { Pilonidal sinus } \\
\text { excision } \\
\text { Hydrocele } \\
\text { Varicose veins } \\
\text { Cholecystectomy } \\
\text { Choledochoduo- } \\
\text { denostomy } \\
\text { Lump in breast } \\
\text { Mastectomy } \\
\text { Appendicectomy } \\
\text { (internal) }\end{array}$ & $\begin{array}{l}2 \\
3 \\
8 \\
1 \\
2 \\
\\
5\end{array}$ & $\begin{array}{l}9 \\
4 \\
1 \\
3 \\
2 \\
1 \\
5 \\
4 \\
2\end{array}$ & $\begin{array}{l}\text { Partial gastrectomy } \\
\text { Vagotomy } \\
\text { Hemicolectomy } \\
\text { Abdomino-perineal } \\
\text { excision of rectum } \\
\text { Laparotomy } \\
\text { Prostatectomy } \\
\text { Minor skin lumps }\end{array}$ & $\begin{array}{l}2 \\
6 \\
4 \\
1 \\
2 \\
2 \\
1\end{array}$ & $\begin{array}{l}4 \\
2 \\
4 \\
1 \\
2\end{array}$ \\
\hline
\end{tabular}

\section{BACTERIOLOGICAL RESULTS}

Preoperative skin plates-Of the 46 patients in group 1, 19 had 39 pathogenic organisms found on the preoperative skin plates, whereas of the 46 in group 2, 20 had 29 pathogenic organisms. There was thus no difference in the incidence of pathogenic organisms between these two groups. Of those who received delayed preparation (four hours before operation) none of the shaved patients had pathogenic organisms, and one in group 2 cultured $E$ coli and Proteus spp (from an infected pilonidal sinus). Among those who were prepared early (20 hours before operation), however, 19 of the 20 who were shaved had skin pathogens whereas 19 of the 26 who received depilatory cream had pathogens. Although the numbers were small this difference was significant $(P<0.05)$. Staph aureus was the commonest single organism encountered and when the numbers of these colonies were considered the colony count in the depilatory group was also significantly lower than the count in the shaved group $(P<0.05)$ (table II).

TABLE II-Colony counts from preoperative skin plates

\begin{tabular}{|c|c|c|c|c|c|c|}
\hline \multicolumn{4}{|c|}{ Group 1} & \multicolumn{3}{|c|}{ Group 2} \\
\hline & $\begin{array}{l}\text { Colony } \\
\text { count }\end{array}$ & $\begin{array}{c}\text { No of } \\
\text { patients }\end{array}$ & $\begin{array}{c}\text { Mean } \\
\text { count/ } \\
\text { patient }\end{array}$ & $\begin{array}{l}\text { Colony } \\
\text { count }\end{array}$ & $\begin{array}{c}\text { No of } \\
\text { patients }\end{array}$ & $\begin{array}{l}\text { Mean } \\
\text { count/ } \\
\text { patient }\end{array}$ \\
\hline 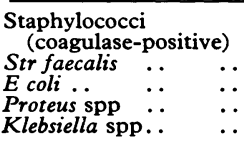 & $\begin{array}{l}876^{*} \\
180 \\
678 \\
1 \\
121\end{array}$ & $\begin{array}{r}19 \\
9 \\
5 \\
1 \\
5\end{array}$ & $\begin{array}{r}46 \\
20 \\
136 \\
1 \\
25\end{array}$ & $\begin{array}{l}440^{*} \\
105 \\
69 \\
16 \\
17\end{array}$ & $\begin{array}{r}17 \\
4 \\
5 \\
1 \\
2\end{array}$ & $\begin{array}{r}26 \\
26 \\
14 \\
16 \\
9\end{array}$ \\
\hline Total & 1856 & & & 647 & & \\
\hline
\end{tabular}

$* \mathrm{P}<0.05$.

Operative wound swabs-There was no statistical evidence that either method of preparation had good or bad effects on the wound swab results at the end of operation. In group 1 two patients produced Gram-negative organisms thought to be due to operative contamination. In group 2 two patients had coagulase-positive staphylococci on the wound swab, and two patients cultured Str faecalis, the latter organisms also thought to be due to operative contamination (hemicolectomy and choledochoduodenostomy).

\section{WOUND HEALING}

The wound grades on the second and fifth days after operation are shown in table III. There was no significant difference in wound healing between group 1 and group 2 .

TABLE III-Wound grades

\begin{tabular}{|c|c|c|c|c|c|c|c|c|c|c|c|c|c|}
\hline \multirow{2}{*}{\multicolumn{2}{|c|}{ Grade: }} & \multicolumn{6}{|c|}{ Day 2} & \multicolumn{6}{|c|}{ Day 5} \\
\hline & & 0 & 1 & 2 & 3 & 4 & 5 & 0 & 1 & 2 & 3 & 4 & 5 \\
\hline $\begin{array}{l}\text { Group } 1 \\
\text { Group } 2 \ldots\end{array}$ & .. & $\begin{array}{l}40 \\
42\end{array}$ & $\begin{array}{l}6 \\
4\end{array}$ & & & & & $\begin{array}{l}34 \\
37\end{array}$ & $\begin{array}{r}10 \\
6\end{array}$ & $\begin{array}{l}1 \\
2\end{array}$ & 1 & 1 & \\
\hline
\end{tabular}




\section{ANTIBACTERIAL EFFECT}

The antibacterial effect of a 1/3 dilution of Ipso against four bacterial species is shown in table IV. Less than 50 organisms $/ \mathrm{ml}$ were detected after one hour in Ipso, and no growth resulted from overnight culture with $20 \mathrm{ml}$ nutrient broth. A heavy inoculum of Ps aeruginosa was killed after 20 minutes in Ipso (table V). The depilatory cream thus showed both bacteristatic and bactericidal properties.

TABLE IV-Results of tests of antibacterial effect of depilatory cream

\begin{tabular}{|c|c|c|c|c|}
\hline & \multicolumn{4}{|c|}{ Organisms $/ \mathrm{ml}$} \\
\hline & $\underset{\text { Aeruginosa }}{P S}$ & E coli & $\underset{\text { faecalis }}{S t r}$ & $\begin{array}{l}\text { Staph } \\
\text { aureus }\end{array}$ \\
\hline 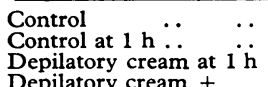 & $\begin{array}{l}4 \cdot 1 \times 10^{5} \\
1 \cdot 7 \times 10^{5} \\
\quad<50\end{array}$ & $\begin{array}{l}0.9 \times 10^{5} \\
0.7 \times 10^{5} \\
<50\end{array}$ & $\begin{array}{c}2.3 \times 10^{5} \\
1.2 \times 10^{5} \\
<50\end{array}$ & $\begin{array}{l}5.8 \times 10^{5} \\
3.3 \times 10^{5} \\
\quad<50\end{array}$ \\
\hline $20 \mathrm{ml}$ nutrient broth & NG & NG & NG & NG \\
\hline
\end{tabular}

NG $=$ No growth.

TABLE V-Results of tests of antibacterial effect of depilatory cream

\begin{tabular}{|c|c|c|c|c|}
\hline & & & & $\begin{array}{c}\text { Ps aeruginosa } \\
\text { viable count } / \mathrm{ml}\end{array}$ \\
\hline $\begin{array}{l}\text { Control } 1 \mathrm{~min} \\
\text { Depilatory cream } 1 \mathrm{~min} \\
\text { Depilatory cream } 10 \mathrm{~min} \\
\text { Depilatory cream } 20 \mathrm{~min}\end{array}$ & $\begin{array}{l}\because \\
\because \\
\because\end{array}$ & $\begin{array}{l}. \\
\therefore \\
. .\end{array}$ & $\begin{array}{l}\because \\
\because \\
\because\end{array}$ & $\begin{array}{l}1.4 \times 10^{5} \\
1.2 \times 10^{5} \\
1.0 \times 10^{5} \\
\quad \mathrm{NG}\end{array}$ \\
\hline
\end{tabular}

$\mathrm{NG}=$ No growth

\section{PATIENT ACCEPTABILITY}

No patient who used the depilatory cream complained of discomfort during preparation, and only one, who had tinea cruris, had a delayed reaction. Many patients in group 1 observed that shaving was uncomfortable and several had obvious skin damage. While no patient in group 1 shaved himself, 26 in group 2 were able to use the cream themselves, under observation. No patient in group 2 complained of discomfort and prickling during regrowth of hair, whereas over half of the patients in group 1 did so.

$\cos T$

The depilatory cream proved to be cheaper than shaving. Twentyfive grams prepared an area of $250 \mathrm{~cm}^{2}$ (average hernia repair) at a cost of $25 p$ compared with $80 p$ for the average cost of a shave, taking into account the time of staff and the disposable equipment used.

\section{Discussion}

While removal of hair from the operative site is required almost universally by surgeons, shaving has remained the method of choice for many years despite the knowledge that micro-organisms enter the visible and microscopic defects produced in the skin, increasing the risk of wound infection, especially if preparation is performed the day before operation. ${ }^{1-3}$ It seems, therefore, that if an efficient, safe, and inexpensive alternative could be found it should have a definite place in preoperative preparation.

The depilatory cream proved to be efficient; in no case was hair removal inadequate. It was also safe, and only one patient with tinea cruris complained of discomfort. Furthermore, it also proved to be cheaper than shaving.

Despite a significant reduction in colony counts in those who received depilatory cream early compared with those who were shaved early, the number of patients studied did not allow a significant reduction in wound infection to be shown. Although most wound infections are not due to skin pathogens, this form of preparation theoretically reduces the risk of such infection.

It is well known that many creams can be readily colonised by pathogenic bacteria and that the use of these from multidose containers is potentially hazardous. We have been shown that this risk is not present with Ipso.

A practical advantage of a depilatory cream is its ease of use in areas that are classically difficult to shave-for example, the thoracic wall in thin patients with pronounced intercostal grooves, the natal cleft, perineum, and any site with underlying acute inflammation which is tender to touch. Not only can the cream be applied to almost any anatomical site but also many patients are able to carry out the whole procedure themselves after brief instruction. A common complaint after shaving is the discomfort and itching that occurs during hair regrowth. This has not been found in patients who have used depilatory cream, for the tip of the growing hair is softly pointed rather than a firm chisel-edged shape.

We thank Mr David Cadman (Knox Laboratories Ltd) for providing the depilatory cream Ipso used in this work. For their bacteriological help, we are indebted to Dr D W Burdon and Mr R W Smyth (General Hospital, Birmingham) and Dr C R Knappett and Mr B Statham (North Staffordshire Royal Infirmary).

\section{References}

${ }^{1}$ Altemeier, W A, Infection in Hospitals. Epidemiology and Control, ed R E O Williams and R A Shooter, p 209. Oxford, Blackwell, 1963.

${ }^{2}$ Seropian, R, and Reynolds, B M, American fournal of Surgery, 1971, 121, 251.

3 Parker, M J, Contact, 1973, p 13.

4 Miles, A A, and Misra, S S, Fournal of Hygiene, 1938, 38, 732. 